\title{
ANALYSIS OF THE CURRENT STATE OF FORMATION AND ESTABLISHMENT OF BOUNDARIES OF THE UNITED TERRITORIAL COMMUNITIES
}

Аврамчук Б.O., Ph.D., senior lecturer

Лошакова Ю.A., Ph.D. student

scientific adviser Butenko. E.V. Ph.D., Associate Professor

Email:yulialoshakova5@gmail.com

The National University of Life and Environmental Sciences of Ukraine

In the current conditions of decentralization and voluntary community integration, there is a need for a comprehensive, up-to-date, and high-quality study of their resource potential, distribution, and prospects for future community development. The most pressing issue for communities is the issue of the specific definition of their boundaries, planning, use, and protection of land, especially with regard to the authority to dispose of land resources outside the settlement.

The article analyzes the constitutional basis of the administrative-territorial system and local self-government in Ukraine, the basic legislation, and the peculiarities of its application in the conditions of change. It is established that in the absence of the adoption of relevant laws, changes to existing ones, the incompleteness of implementation of measures on decentralization of power, untimely resolution of problems arising in the process of implementation of land management reform within the jurisdiction of local councils, the process of reforming local self-government is hampered.

Keywords: sustainable development, spatial planning, sustainable use, borders, administrative and territorial structure, decentralization.

Relevance. The term "united territorial community" (hereinafter referred to as the $\mathrm{CAG}$ ) is used to describe urban and regional development policy in Ukraine. In this context, OTG is seen as a well-established territorial community, able to 
form an independent position on key local development issues and ready to take joint action to address common problems.

In each of the newly created communities there is a practical problem - to acquire the status of capable and self-sufficient formation, which will allow to manage effectively all the assets located in its territory. The united territorial communities are not recognized as subjects of administrative and territorial structure in the Constitution of Ukraine, therefore the boundaries of these local self-government bodies cannot be formed by the current legislation. Regarding the existing boundaries of the settlements that are part of the community, it should be noted that they often do not meet the established limit [2] or are not established at all.

The fact is that newly formed united territorial communities can become the basis of the administrative-territorial structure of the new country and the basic unit of the settlement system. In addition, the so-called "locality" principle will be introduced at the community level, according to which local governments are stewards of land outside settlements. Regional spatial development, curbing the rapid decline in demographics in small towns and rural settlements, and providing social infrastructure that operates locally are far from a complete list of areas of responsibility for newly created communities.

The absence of established boundaries of administrative-territorial entities leads to exceeding their powers of executive authorities and local self-government when adopting administrative documents on land use.

The purpose of the article to substantiate the state of normative legal support of formation and establishment of borders of the united territorial communities, to define directions of its improvement.

Analysis of recent research and publications. Questions of efficiency of management of land resources and land use at the present stage in the country were researched by the following scientists: V.E. Dankevich, E.M. Dankevich, A.G.Martin, O.M. Chumachenko, A.Ya. Sokhnich, A.M. Tretyak, IG Kolganova. 
The following scientists have made significant contributions to the formation and establishment of boundaries of newly formed territorial communities, the efficiency of agricultural land use, and the reduction of problems of land legislation: Dobryak, A.M. Moskalenko, J.M. Dorosh, R.M. Degree, M.G. Degree, OV Khodakivska, etc.

Results of the research and their discussion. In the current context of decentralization and voluntary community association, the question of the jurisdiction of new entities and their resources arises. The opportunity for united territorial communities to have a clear picture of their resources, their allocation, and future prospects is one of the challenges facing local governments that require effective and rapid response.

One of the most pressing issues for communities is the issue of properly defining their boundaries, as well as the planning, use, and protection of land within these territories, especially when granting communities the authority to dispose of land resources outside settlements.

The main purpose of defining the boundaries of the community is to streamline the administrative and territorial structure and to legally establish the actual boundaries. This will ensure the authority of territorial communities in the regulation of land relations in the territory, which is its spatial basis and unites in one whole residential, public, industrial development, engineering infrastructure, public lands, recreational and other purposes [2].

During the years of independence of Ukraine, legislation was formed that defines the system of public authorities, the procedure for their formation, the resource base of activity, and powers. However, for various reasons, a system of administrative and territorial structure has not been formed in Ukraine that has been developed in a way that would meet the needs of its development. Ukraine is almost the only country in Europe that does not yet have a law governing the creation and liquidation of administrative-territorial units, maintaining their register and establishing a primary register of addresses on this basis [4]. 
There are a number of problems of the administrative and territorial structure of Ukraine:

- lack of uniform classification and order of classification of existing administrative-territorial units in the corresponding category;

- assignment to the system of administrative-territorial units of settlements, the inconsistency of really existing categories of settlements with the Constitution of Ukraine;

- disorder of the structure of the administrative-territorial system;

- excessive difference of administrative-territorial units of one level and category in terms of population, area, other parameters;

- inconsistency of many administrative-territorial units with their personnel, resource and organizational potential [3];

- within the territory of some administrative-territorial units of territories, there are ATOs belonging to other units of the same level of ATU;

- irrational delimitation of separate administrative-territorial units;

- excessive number of administrative-territorial units of the basic (about 12 thousand) and district level (about 500), which reduces the effectiveness of territorial management and control $[3,5]$.

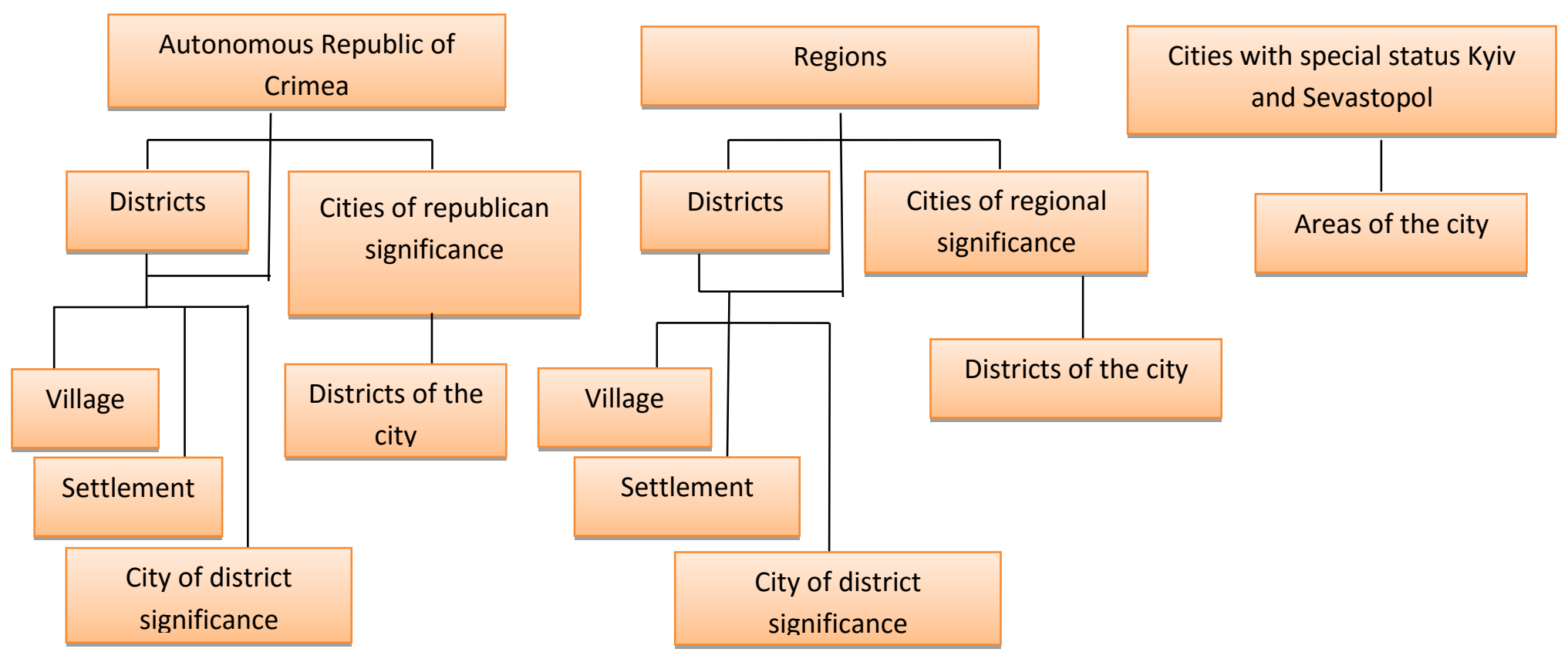




\section{Figure.1 The system of administrative-territorial organization of Ukraine}

\section{Source: generated by the author for [5]}

During the four years of the decentralization reform, the boundaries of no unified territorial community have been established and, as a result, have not been included in the State Land Cadastre.

Today in Ukraine there are a number of problems related to the formation and establishment of the boundaries of united territorial communities, as there is no regulated legislative mechanism for their formation and approval.

Some politicians have long argued that the reform of local self-government and territorial organization of power (hereinafter the reform of decentralization), which is carried out in accordance with the Reform Concept Кон333-r of 01.04.2014, does not comply with the Constitution of Ukraine - OTG can not be the basis of new ATU. As is typical of the main law, the Constitution of Ukraine regulates the issue of administrative system in a rather general form. The only article that establishes certain direct rules on ATU is Article 133. However, it cannot be applied outside Articles 85, 92, 140, 142 and 243. It can be seen from the content of Article 133 that the ATU system includes different categories of sub- objects of regulation: the ARC, regions, districts, cities, districts in cities, towns and villages. In this list there are both classic administrative-territorial units, such as regions and districts, as well as settlement units, ie cities, towns and villages that belong to the category of urban planning. This gives grounds to claim that the subjects listed in Article 133 can be interpreted as administrative-territorial units [7]. If we consider Article 133 in conjunction with Articles 85 and 92, it follows that the territorial organization of Ukraine is determined exclusively by the laws of the countries, and powers over districts, changes in districts and cities are exercised by the Verkhovna Rada of Ukraine and cannot be transferred to other bodies. Therefore, in order to resolve issues related to the establishment of levels (categories) of administrative-territorial units, the order of their formation, reorganization / liquidation, determination of the status of settlements, there must be a separate law. 
The provisions of Article 140 state that local self-government bodies in Ukraine operate in the territorial community (village, settlement, city councils), rayon (rayon council) and oblast (oblast council). In this case, the basic or primary subject of local self-government is the actual territorial community. Together with the aforementioned articles, Article 140 provides grounds for determining the subject and requirements for changing the law on the administrative-territorial structure of the country [7]. Having analyzed the above rules, it should be noted that there should be a separate regulatory document to address all issues that concerning the establishment of categories (levels) of administrative-territorial units, the order of their formation, reorganization, and liquidation, determination of the status of settlements and their assignment to different levels, etc.

The reform of local self-government and territorial organization of government, which began in 2014 on the basis of the creation of united territorial communities on a voluntary basis, is a good illustration of the fact that constitutional norms, which were partially criticized by experts, did not hinder reform. The created OTGs essentially became the territorial basis of the capable local self-government of the basic level - the administrative-territorial unit. Now it is only necessary to organize at the level of law the entire system of administrativeterritorial organization of Ukraine [6].

Based on the Law of Ukraine "On Voluntary Association of Territorial Communities", village, settlement, and city councils are voluntarily united into united territorial communities [8]. The territory of the OTG must be an inseparable boundary and be formed by the external boundaries of the councils that formed it as a result of the merger. This, of course, will lead to a significant increase in the area, population, and expansion of the powers of local governments through the transfer of their powers to one village, town, or city council of the newly created territorial association [8]. The absence of OTG borders registered in the State Land Cadastre is on the way to the effective management of land resources within the powers of local governments. 
Another issue facing decentralization reform is the determination of the legal status of lands outside settlements. Previously, state-owned agricultural lands outside settlements are managed by the State Service for Geodesy, Cartography, and Cadastre. A significant part of these lands was leased at the lowest rent - 1-3\%, ie at prices below market, and the united territorial communities were completely removed from the disposal of such state-owned land. This increased the risks of corruption, and communities underfunded their development. Local governments actually had an impact on only $12 \%$ of their own territories and were deprived of the opportunity to effectively plan their development [3].

As of March 4, 2020, the State Geocadastre and its territorial bodies transferred to the established OTG in the ownership or use of state-owned agricultural land in the amount of 1.5 million hectares (Fig.2) [1].

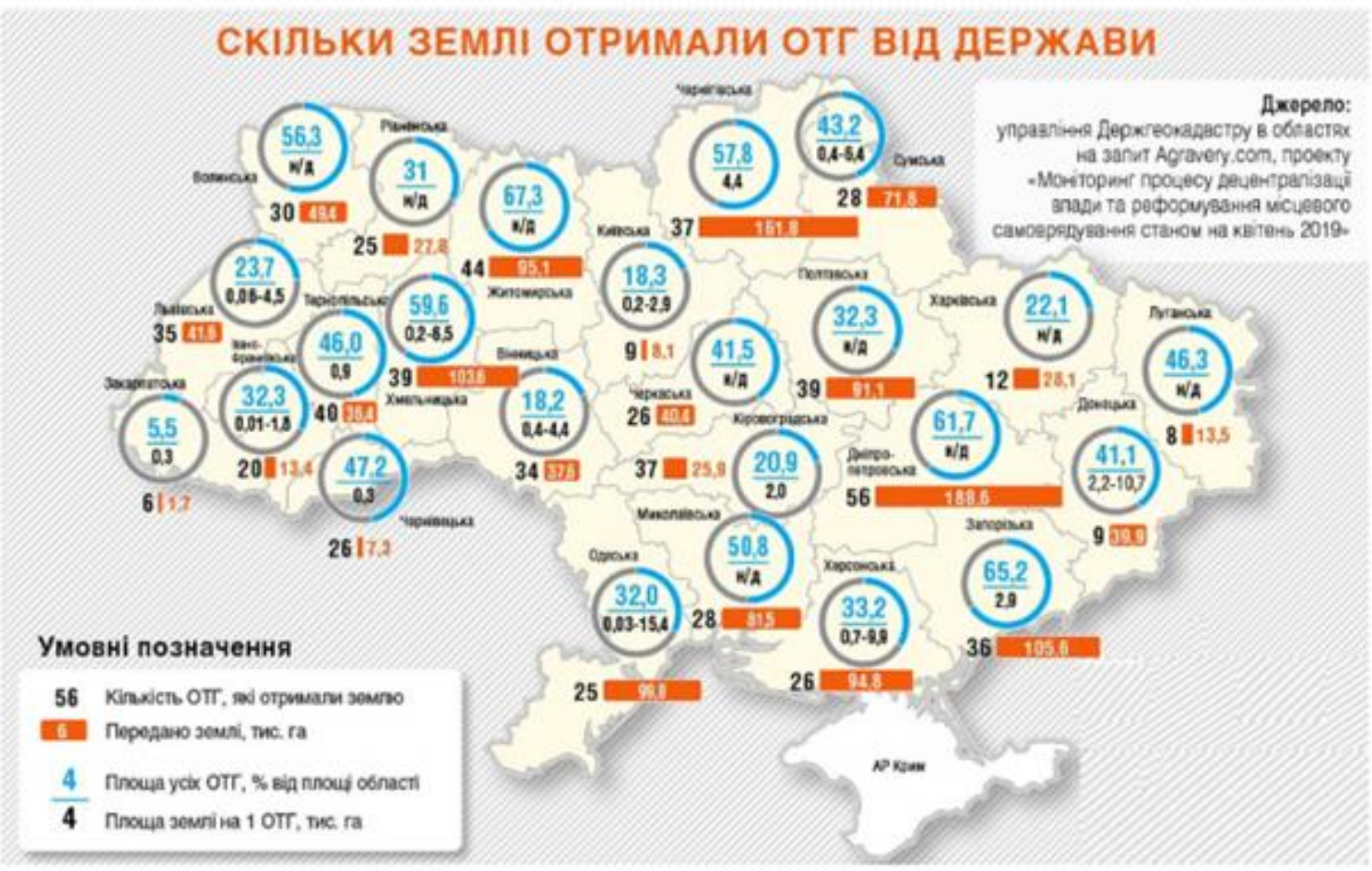

Fig.2 Status of transfer / receipt of agricultural land OTG as of April 2019 Source: [1]

One of the serious shortcomings of the introduction of local selfgovernment, the formation of a rational system of land use and the creation of ecologically balanced landscapes is the legally unregulated issue of establishing boundaries, developing schemes and land management projects of a single land 
resource space of united territorial communities of the village, settlement and city councils [12].

In the vast majority, the boundaries of the ATUU are not fixed in kind (on the ground) or border structures are lost, and therefore disputes between territorial authorities over the passage of the boundaries of the ATUU are almost impossible to resolve through negotiations. In fact, resolving the relevant issues becomes a manifestation of political will, not technical procedures. According to the Land Code of Ukraine, namely to the requirements of Articles 173, 174, "the boundaries of the district, village, town, city, district in the city are established and changed by land management projects to establish (change) the boundaries of administrativeterritorial units".

As of January 1, 2020, there are 28,299 settlements in Ukraine (excluding the Autonomous Republic of Crimea and the temporarily occupied territories of Donetsk and Luhansk oblasts), of which borders have been established in 21,702 settlements, which is $76.7 \%$ of their total number, including: according to the State Land Cadastre as of 27.01.2020 the State Land Cadastre includes information on the boundaries of 6,060 settlements [1].

Thus, the legislation should determine the effective procedure for arbitration of relevant disputes. The rights and responsibilities for resolving disputes between territorial administration bodies concerning the boundaries of the ATUU should be granted to higher collegial bodies of state administration or a specially created authority for these purposes.

Conclusion. It is established that the formation of the boundaries of the united territorial communities is carried out on the legislative basis of the formed boundaries of the territories of village, settlement and city councils. In such cases it is a question of improvement of the land management process of restoration of borders of territories of village, settlement and city councils. If it is necessary to change the existing boundaries of the territories of village, settlement and city councils as a result of the formation of the boundaries of the united territorial 
communities, it is necessary to improve the current legal and regulatory framework.

\section{Reference}

1. Monitoring the process of decentralization of power and reform of local self-government as of February 18, 2020 Ministry of Regional Development, Construction and Housing and Communal Services of Ukraine. Available at: https://decentralization.gov.ua/mainmonitoring 2. Dorosh Y. (2018). Problemy formuvannya ta vstanovlennya mezh ob'yednanykh terytorial'nykh hromad: zemlevporyadno-pravovyy aspekt [Problems of formation and establishment of boundaries of united territorial communities: land management aspect]. Land management, cadastre and land monitoring, 4.

3. The status of settling boundaries of settlements. Available at: https://land.gov.ua/info/vstanovlennia-mezh-naselenykh-punktiv/

4. Lisova T. (2017). Udoskonalennya administratyvno-terytorial'noho ustroyu krayiny [Improvement of the administrative and territorial structure of the country]. Economist.

5. Draft Law of Ukraine on the Principles of the Administrative and Territorial System of Ukraine. Available at: http://w1.c1.rada.gov.ua/pls/zweb2/webproc4_1?pf3511=63508

6. Constitution of Ukraine. Available at: https://zakon.rada.gov.ua/laws/show/254\%D0\%BA/96-\%D0\%B2\%D1\%80

7. On the issue of administrative-territorial reform and constitutional regulation. Available at: https://decentralization.gov.ua/news/11333

8. Law of Ukraine "On voluntary association of territorial communities". Available at: http://zakon4.rada.gov.ua/laws/show/15719/print 1473700920200673

9. The Civil Code of Ukraine. Available at: https://zakon.rada.gov.ua/laws/show/435-15

10. Land Code of Ukraine. Available at: https://zakon.rada.gov.ua/laws/show/2768-14

11. Order No. 60-r of 31.01.18 "Issue of Transfer of State-Owned Agricultural Land to Communal Property of United Territorial Communities". Available at: https://www.kmu.gov.ua/npas/pitannya-peredachi-1

12. Novakovsky L. (2018). Stan ta problemy zemleustroyu OTH u konteksti pidvyshchennya yikh finansovoyi stiykosti [The status and problems of land use management in the context of improving their financial stability]. Land Gazette of Ukraine, 3.

13. Law of Ukraine "On the State Land Cadastre". Available at: zakon.rada.gov.ua/laws/show/3613-17. 
Аврамчук Б., Лошакова Ю.

\section{АНАЛІЗ СУЧАСНОГО СТАНУ ФОРМУВАННЯ ТА ВСТАНОВЛЕННЯ МЕЖ ОБ’ЄДНАНИХ ТЕРИТОРІАЛЬНИХ ГРОМАД}

В сучасних умовах децентралізації та добровільного об’єднання громад виникає потреба в комплексному, актуальному та якісному дослідженні їх ресурсного потенціалу, розподілу та перспективи майбутнього розвитку громади. Найбільш актуальним для громад $є$ питання про конкретне визначення їх меж, планування, використання та охорону земель, особливо це стосується повноважень у розпорядженні земельними ресурсами за межами населеного пункту.

В статті проаналізовано конституційну основу адміністративно-територіального устрою та місцевого самоврядування в Україні, базове законодавство та особливості його застосування в умовах змін. Встановлено, що за відсутності ухвалення відповідних законів, змін до існуючих, незавершеності реалізації заходів щодо децентралізації влади, несвоєчасного вирішення проблем, що виникають в процесі впровадження реформи щодо управління земельними ресурсами в межах юрисдикції місцевих рад, процес реформування місцевого самоврядування стримується.

Ключові слова: сталий розвиток, просторове планування, стале використання, межі, адміністративно-територіальний устрій, децентралізація.

\section{Аврамчук Б., Лочакова Ю.}

\section{АНАЛИЗ СОВРЕМЕННОГО СОСТОЯНИИ ФОРМИРОВАНИЯ И УСТАНОВЛЕНИЯ ГРАНИЦ ОБЫЕДИНЕННЫХ ТЕРРИТОРИАЛЬНЫХ ГРОМАД}

В современных условиях децентрализации и добровольного объединения громад возникает потребность в комплексном, актуальном и качественном исследовании их ресурсного потенциала, распределения и перспективы будущего развития сообщества. Наиболее актуальным для громад является вопрос о конкретном определения их границ, планирования, использования и охрана земель, особенно это касается полномочий в распоряжении земельными ресурсами за пределами населенного пункта.

В статье проанализированы конституционная основа административнотерриториального устройства и местного самоуправления в Украине, базовое законодательство и особенности его применения в условиях изменений. Установлено, что при отсутствии принятия соответствующих законов, изменений в существующие, незавершенности реализации мер по децентрализации власти, несвоевременного решения проблем, возникающих в процессе внедрения реформы по управлению земельными 
ресурсами в пределах юрисдикции местных советов, процесс реформирования местного самоуправления сдерживается.

Ключевые слова: устойчивое развитие, пространственное планирование, устойчивое использование, границы, административно-территориальное устройство, децентрализация. 